\title{
SL003 Social Cognition and the Human Brain 社会的認知と人間の脳
}

\author{
講演者 : Ralph Adolphs (California Institute of Technology) \\ 企画者 : 坂上 雅道 (玉川大学) \\ 司会者: 大久保街亜 (専修大学)
}

\section{講演の内容}

Humans are an intensely social species, an aspect of our behavior that social psychology has long investigated. More recently, findings from neuroscience have informed our understanding of how we process social information, how this influences our emotions and behavior, and how it can break down in diseases such as autism. I will provide an overview of work in my laboratory on face processing, on the role of the amygdala, and on the mechanisms underlying autism.

\section{主な著書・論文}

Adolphs, R. (2002). Neural systems for recognizing emotion. Current Opinion in Neurobiology, 12, 169-178.

Adolphs, R. (2003). Cognitive neuroscience of human social behavior. Nature Reviews Neuroscience, 4, 165-178.

Adolphs, R., Tranel, D., \& Damasio, A. R. (1998). The human amygdala in social judgment. Nature, 393, 470-474.

Adolphs, R., Tranel, D., Damasio, H., \& Damasio, A. (1994). Impaired recognition of emotion in facial expressions following bilateral damage to the human amygdala. Nature, $\mathbf{3 7 2}$, 669-672.

Adolphs, R., Tranel, D., Damasio, H., \& Damasio, A. (1995). Fear and the human amygdala. The Journal of Neuroscience, 15, 5879-5892.

Bechara, A., Tranel, D., Damasio, H., Adolphs, R., Rockland, C., \& Damasio, A. R. (1995). Double dissociation of conditioning and declarative knowledge relative to the amygdala and hippocampus in humans. Science, 269, 1115-1118. 